\title{
Preliminary Characteristics of Ecological and Socioeconomic Components and their Interaction within the Long Term Socioecological Research Platform of Latvia
}

\author{
Viesturs Melecis, Institute of Biology, University of Latvia, Zaiga Krisjane ${ }^{1}$, Maris Klavins ${ }^{2},{ }^{1-2}$ Faculty of Geography \\ and Earth Sciences, University of Latvia, Juris Aigars, Institute of Aquatic ecology, Didzis Elferts ${ }^{3}$, Janis Viksne ${ }^{4}$, \\ ${ }^{3-4}$ Institute of Biology, University of Latvia
}

\begin{abstract}
Review of previous ecological and socioeconomic studies performed in the drainage basin of Lake Engure - the long-term socioecological research region $(\mathrm{LT}(\mathrm{S}) \mathrm{ER})$ of the National LTER network of Latvia has been given. A number of studies on biodiversity and ecosystem structure of the region were published during the last century. There have been no special socioeconomic studies of the region till now. The data should be collected mostly from different archives and statistical summaries. Biodiversity of the region has been formed over the centuries and is strongly dependent on socioeconomic factors.
\end{abstract}

Keywords - Biodiversity, ecosystems, Ramsar site, wetlands

\section{INTRODUCTION}

The declared aim of the European Community to halt the decline of biodiversity at the local, national and regional levels by 2010, unfortunately, has not been achieved [8]. Effective policies to slow the rate of anthropogenic degradation of ecosystems and biodiversity loss should reduce socioeconomic pressures on biodiversity, either directly or by modifying their underlying socioeconomic driving forces. The design of such policies is currently hampered by the limited understanding of socioeconomic drivers and pressures on biodiversity, as well as by the lack of data, indicators and models [9].

Since its establishment, the International Long-term Ecological Research network (ILTER) has focused on longterm studies of ecosystem structure and functioning. It provides a vast array of different data sets concerning biodiversity and ecosystems. Human influence is mostly considered as one of the external factors.

During the ILTER meeting in Stara Lesna (Slovakia) in 2008, a new research strategy was set forward which focused on threshold interaction between environmental and socioeconomic dynamics at multiple scales and possibly forecast the effects of these interactions on biodiversity and ecological resilience. These objectives set a new challenge to the development of methodological approaches in studying complex landscape-level interactions between humans and ecosystems in different climate zones and under different economies. Each LTER country was asked to select a Longterm Socioecological Research (LT(S)ER) platform to meet these new research demands. At present, the metadata base of LTER Europe includes $21 \mathrm{LT}(\mathrm{S}) \mathrm{ER}$ platforms all around EU.
At a workshop of LT(S)ER platform managers in Krusne Hory (Czech Republic) in 2008 and a recent meeting in Helsinki in 2011 some guidelines to implementation of the research programmes in the LT(S)ER platforms have been discussed, in particular concerning the socioecological component of the study.

Latvia selected the Engure region as its LT(S)ER platform. This territory represents the drainage area of coastal Lake Engure. It includes forests and agricultural lands, as well as unique wetlands protected by the national law and the Ramsar Convention. Human activities have been shaping ecosystems and the biodiversity of the region for centuries. However, the region never had large industries and remained mostly as a rural landscape with small fishermen's and farmers' villages [23] and [14]. Therefore, the selection of this region as a LT(S)ER platform will provide good bases for studying the development of the man - nature interactions in the future. At present, the new economic situation has radically changed the previously existing relative balance between man and nature in the region. Implementation of the LT(S)ER should also contribute to ecologically based solution of the problems faced by the region. In 2010 a national cooperative project financed by the Latvian Council of Sciences No 10.0004 "Development of conceptual integrated model of socioeconomic biodiversity pressures, drivers and impacts for the long-term socioecological research platform of Latvia" began with the aim to work out a conceptual model reflecting the main pressures and drivers responsible for the development of biodiversity of the LT(S)ER region. The aim of this article is to provide an overview of the existing data sources concerning the regions biodiversity and socioeconomic characteristics, as well as a preliminary analysis of the existing information on the history of human and nature interactions in the region.

\section{II.ECOLOGICAL CHARACTERISTICS OF THE ENGURE LT(S)ER REGION}

Lake Engure and its drainage basin (about 644 sq. km) together represent one of the most unique natural areas of the Latvia Coastal Lowland. The Engure region is situated in the coastal zone on the western part of the Gulf of Riga. The region includes the Engure Nature Park (19,992 ha), with an aquatory of the Gulf as far as $10 \mathrm{~m}$ isobaths. 


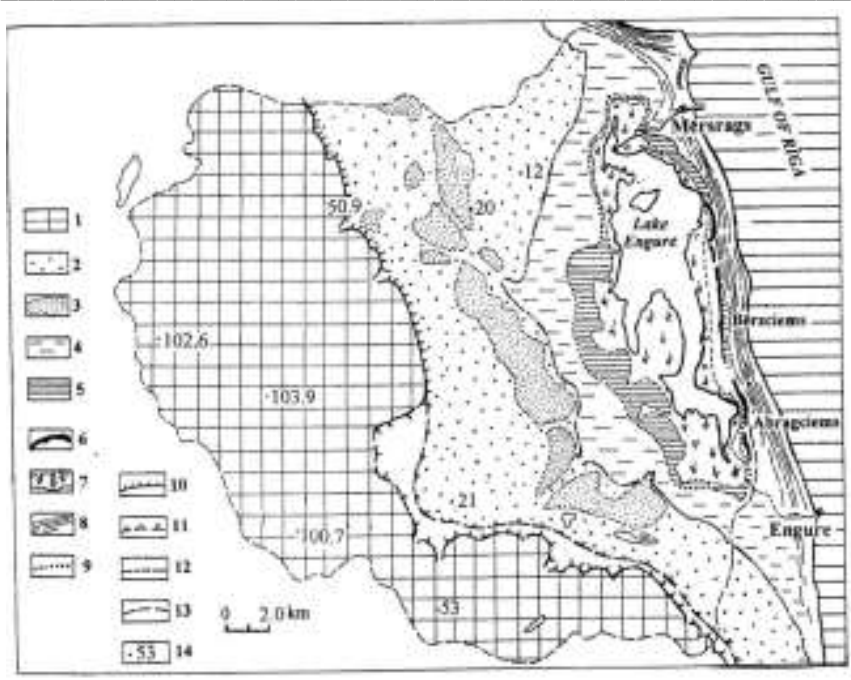

Fig. 1. Main zones of relief of Engure region. 1 - hills of the North Kurzeme Upland; 2 - Baltic Ice Lake plain; 3 - inland dune belt; 4 - Littorina Sea plain; 5 - level plain of Lake Engure after digging of the Mērsrags Canal; 6 range of new dunes; 7 - belt of water-logged meadows, forest and reed-beds of Lake Engure; 8 - belt of parallel dunes of the Engure Spit; 9 - highest shoreline of Lake Engure; 10 - escarpment of the North Kurzeme Upland; 11 - shoreline of the Baltic Ice Lake; 12 - Littorina Sea coastline; 13 - boundary of the Lake Engure drainage basin; 14 - height, meters above sea level (from [6]).

Lake Engure is a remnant of the ancient Littorina Sea formed about 4000 years ago. Fluctuations of the water level in the Littorina Sea caused several separations and rejoinings of the lagoon with the sea. The present coastline of the Baltic Sea has existed for about 2800 years. Then the formerly open bay was transformed into a brackish water lagoon [6].

The density of the hydrological network within the drainage basin and its asymmetry are the result of the development of this area during the glacial and post-glacial periods. The main river network crosses 5 zones of relief of different age and geological structure (Fig. 1) [6]:

- the hills of the North Kurzeme Upland;

- the sloping sandy plain of the Baltic Ice Lake with a unique inland dune belt;

- the waterlogged sandy Littorina Sea plain;

- the wet Lake Engure area.

The relief of the North Kurzeme Upland is very different - hillocks are integrated by dump, boggy hollows. In complete contrast to the North Kurzeme Upland, a sloping plain falls towards the east and south-east and is covered by sand-gravel deposits. The inland dunes represent a relief formation very characteristic of the sands of the Baltic Ice Lake. The dunes formed after the regression of the Baltic Ice Lake under conditions of dominant westerly and north-westerly winds, and when vegetation was poorly developed, can be considered as secondary barriers to natural surface drainage on the Baltic Ice Lake plain [5]. For this reason, large areas of wet forest are located presently in front of the dune belts. The plain of the Baltic Ice Lake is the second largest natural zone of Lake Engure drainage basin, in terms of its area, where, owing to widespread sandy and gravely deposits and a continuous forest cover, surface runoff has been replaced by groundwater seepage in river valleys and along the foot of slopes.
The climate of the region is largely affected by the Riga Gulf. Winters are mild, especially in the coastal area, while summers are relatively cool and rainy. The mean temperature in January is $-4.6^{\circ} \mathrm{C}$, in July $+16.7^{\circ} \mathrm{C}$. Precipitation (average $600 \mathrm{~mm}$ per year) exceeds evaporation by two times which promotes the formation of marshlands in relief depressions.

Lake Engure belongs to the group of shallow lakes (maximal depth $2.5 \mathrm{~m}$ ) filled with organic deposits (thickness of gyttja 4-8 m) and has a uniform temperature regime during the ice-free-season. The bottom is muddy and covered by charophytes. The estimated water exchange is 7 to 16 times annually, or during dry summers once in 3 months, and during flooding up to 4 times a month. The rate of water supply from the drainage basin has an important role in the ecosystem of the shallow Lake Engure. This rapid water exchange is one of the main factors which the circulation of organic and mineral matter in the lake depends on. In years of rapid water circulation, more organic and mineral matter is carried into the lake, which is also reflected in the lake deposits [6].

Chemical composition of the lake water is determined mostly by natural geochemical factors e. g. weathering of aluminosilicates and carbonates providing medium high mineralisation and formation of sulphates in deeper layers by oxidation reactions. The ion composition is dominated by hydrocarbonate, calcium, and magnesium ions. Impact of anthropogenic pollution by heavy metals is insignificant. Most concentrations of metals are influenced mainly by geochemical processes. Observed concentrations of organic pollutants are also relatively low [4].

Chemical analysis of the lake mud showed that the organic content of the lake deposits has grown significantly during the last century, and that the eutrophication and accelerated overgrowing of the lake is more associated with lowering of the lake level rather than with the influx of nutrients. Increased mineral transport has been caused by soil, gully, and river erosion, after the destruction of continuous forest cover and the increase in arable land in the North Kurzeme Upland [6]. The concentrations of heavy metals in the sediments of Lake Engure are at a background level [12]. The network of ditches established during the last century in forests lowered the ground-water level, prevented retention of surface water in low-lying areas, promoted evaporation, and significantly increased the growth of wood. However, these changes promoted the increased groundwater drainage. Also, this clearly raised the flow of groundwater containing humus, and increased concentrations of iron in the main river network and the lake [6].

The morphometric, hydrological, and hydrochemical features of the lake determine the character of plankton and benthos communities. The low phytoplankton biomass is typical of calcareous clear water lakes dominated by charophytes. The macrozoobenthos is dominated by insect larvae. The bacterial counts are relatively high, but low numbers of saprophytic bacteria in water, as well as in the sediment, are typical. Therefore, it could be concluded that endogenous processes dominate in Lake Engure. In its development, the lake has reached the last (dystrophiceutrophic) stage of lake succession [20].

The ecological conditions of the nearby shallow coastal zone of the Gulf of Riga are largely reflecting the quality of 
inflow from the Lake Engure drainage basin. This place is far from the big most polluted rivers of Latvia - the Daugava and Lielupe estuaries and thus receives no local pollution. It has the lowest concentrations of heavy metals in marine sediments and water, in comparison with other coastal aquatories of the Gulf [19]. The data on marine mesozooplankton demonstrated no indication of eutrophication of the shallow waters of this coastal zone [21].

The Engure region is one of the best investigated regions in Latvia in relation to fauna and flora. Since 1997, a detailed survey of the flora of the Lake Engure basin was carried out by applying the method of quadrants [22]. For the study of species occurrence in the Lake Engure Nature Park, a more detailed territorial division (0.25 sq. km quadrants) was developed. A total of 936 vascular plant species and 55 moss species were recorded in the region [7], including 101 species recorded in the Red Data Book of Latvia [1]. The analysis of the floristic composition showed that, along with the indigenous species of Latvian flora, the species composition is affected partly by synanthrophisation: 21 species are adventitious, 59 species can be regarded as escaped and naturalized in natural plant communities.

The region has exclusively rich ornitofauna, including 186 breeding bird species. Due to the high diversity of the presence of species threatened globally and in Europe, as well as due to the great numbers of water birds dwelling here both during breeding periods and migration, the Engure area was included in the Ramsar list in 1995. Ornithological long term research of duck population ecology was established here already in 1958 .

During the last years, certain progress has also been made in studies of invertebrate fauna. Nevertheless, the list of species is still far from being complete. At present. the list includes 202 species of beetles (Coleoptera), 37 species of caddisflies (Trichoptera), 30 species of dragonflies (Odonata), 351 species of flies (Diptera) [11], 60 species of springtails (Collembola) and 59 species of soil dwelling mites (Gamasina) [17].

The Engure region has an exclusively diverse pattern of habitats. It includes 24 NATURA 2000 sites [2]. The region is subdivided in two parts by the border between the WestLatvian geobotanic region and the Coastal geobotanic region. The West-Latvian geobotanic region includes the North Kurzeme Upland where agricultural hillocks are interchanged by damp, boggy hollows and small patches of forests. The basin part belonging to the Coastal geobotanic region is characterised by the highest percent cover of forests (about 60 percent). Pine forests on mineral soils are dominating, mainly Hylocomiosa, less frequently nemoral spruce Oxalidosa. In the relief hollows, large areas are covered by wet forests with Dryopterioso-caricosa as the dominant type. Smaller areas are covered by wet meadows and fens, including floristically-rich calcareous fens [7].

Until now more detailed studies of dune and lake wetland vegetation have been performed within the area. Classification of the seashore vegetation yielded 19 plant community types, most of them are NATURA 2000 sites [13]. The priorities for protection are grey dune and coastal meadow plant communities, including many rare species. The classification based on Landsat satellite imagery [3] yielded 15 mapping classes, including emergent vegetation of paludified habitats.

There are three areas important from the viewpoint of biodiversity within the Engure LT(S)ER region: (i) the Ramsar site; (ii) the coastal dune belt; (iii) the marine coastal macrophyte habitats. The Ramsar site is of high ecological importance as a nesting site of many rare and endangered water bird species. Natural coastal dunes represent unique habitats which have become rare on the coast of the Baltic Sea. Marine macrophyte habitats are of great importance as spawning places of several economically important marine fish species. These habitats are included in the Lake Engure Nature Park. Each of these habitats has specific pressures to biodiversity. The preliminary evaluation of pressures eventually affecting the Ramsar site is connected with the inputs to Lake Engure from its drainage basin.

\section{SOCIOECONOMICAL CHARACTERISTICS OF THE ENGURE LT(S)ER REGION}

The geological formation of the territory after the last glaciations had the decisive influence on the region's population. Farms and villages are concentrated mainly on the uplifts of the western part of the region with loamy soils, as well as on the narrow belt that separates Lake Engure from the sea. The middle part of the region representing the waterlogged, sandy Littorina Sea Plain and the wet Lake Engure area is underpopulated and covered with pine forests and bogs. During the last century several unsuccessful attempts to drain this part of the territory were made, because it is crossed by a dense network of ditches falling in several small rivers - a part of the drainage basin of the lake [6].

The region has gone through at least three different types of economic development during the last two centuries: (i) a period of farmland agriculture until the 1950s; (ii) a period of socialistic intensive agriculture 1950-1991; (iii) decrease in agricultural activities after privatization and the denationalization of lands since 1991 in independent Latvia. However, the region has never had any big industries and has remained mostly as a rural landscape.

The traditional settlement type in the coastal zone was the former fishermen's village, which is characterized by its linear structure along the seashore and farmsteads inland. Digging of the Mērsrags Canal in 1842 had a good impetus to the development of the local village. A sea port with a lighthouse and a shipyard was built there. Fishing and fish processing was developed in several coastal villages, providing working places for local people. In recent decades, overfishing and conservation restrictions imposed by the European Union have caused a decline in the fishery of the region and most fish processing factories were closed. Nowadays, the highest number of employees is in the service sector (wholesale, catering, tourism and leisure industries). The previous fisherman villages have been subject to a wave of summer cottage, second home and guest house construction.

Since ancient times, the inland territories of the region (except the forested lowland) were lands of active agriculture, including corn and vegetable production, dairy farming and fruit-growing. In our days, there are also small woodworking enterprises. However, a number of small farms in the region 
are abandoned and the previous agricultural lands and meadows are overgrown by bushes.

There have been no special studies performed on the socioeconomic characteristics of the region. The data on the population numbers, the infrastructure and economy of the region are scattered in various statistical reports and archives, and, therefore, this material needs to be collected and reviewed.

\section{INTERACTION BETWEEN THE SOCIOECONOMICAL FACTORS AND BIODIVERSITY OF THE REGION}

The recent biodiversity of European landscapes has been formed under permanent human influence. Agricultural practice and settlement building activities started about 8000 years ago. This long history of land management has led to development of specific agro-ecosystems and associated biodiversity that can only be maintained under specific agricultural practices [18], because we should consider those ecosystems as "human ecosystems" in the sense of Z. Naveh [15] and [16]. Every change in landscape management practice exerts new pressure on the previously formed ecosystem structure and biodiversity. In this respect, man steps out as a specific regulator factor of the ecosystem structure, modifying it either intentionally or unintentionally by various socioeconomic activities. According to the intermediate disturbance hypotheses [10], the maximum species diversity of the landscape can be observed under the low-intensity land use. The recent biodiversity of ecosystems in Latvia to a great extent is a heritage from the complex interactions of the socio-economic and ecological processes during the earlier centuries. The problem lies in the fact that during the second part of the $20^{\text {th }}$ century human induced disturbances significantly increased beyond the tolerance limits of most ecosystems formed under extensive economies. As a consequence - a dramatic loss of species and the increasing needs for nature conservation.

The Engure region is not an exception in this respect. It seems that the first available documented transformation of the region was digging of a canal in 1842 which connected the northern end of the lake with the sea near the village Mērsrags [23]. After digging the canal, the water level of the lake fell by about $1-2 \mathrm{~m}$ according to different historical sources, and the area of the lake shrunk two-fold from about 90 to $45 \mathrm{~km}^{2}$. The main purpose of this transformation was to obtain new agricultural lands. The later part of these areas turned to sedge Carex spp. meadows and was used for hay harvesting. However, most of the territory of the previous bottom of the lake in our days is covered by low-productive forests and fens. The canal was effective not only by causing the lowering of the water level, but it also allowed for an impact of sea water on the lake freshwater ecosystems. When the sea level rose, the water was brackish even in the central part of the lake, occasionally even marine species flatfish Pleuronectes flesus were caught there [23].

Lake overgrowth is partly a natural process which has been going on ever since lakes were formed after the glacial period. However, human influence and land use in the lake drainage basin in particular, can accelerate the process by increasing of nutrient loads. Lake Engure is subjected to gradual overgrowth by reeds Phragmites australis. Merging of separate reed-beds is a significant threat to the lake ecosystem, in particular for nesting places of water birds.

Since the early 1990s, after private owners regained control of their lands and large socialistic state farms (kolkhozes) were abolished, a number of private farms appeared to be unprofitable. Therefore, large tracts of agricultural land were abandoned and overgrown with bushes and forest. This might change the structure of the previously existing community. A number of habitats, such as the Boreal Baltic coastal meadows, Molinia meadows on calcareous, peaty or clayeysilt-laden soils, Northern boreal alluvial meadows and Calcareous fens with Cladium mariscus and species of the Caricion davalliana, are now endangered. A lot of animal species preferring open habitats became endangered too. Among them are such protected bird species as corn crake Crex crex. Certain measures have been introduced by the state, such as area payments, to prevent the overgrowth of the land [2].

On the other side, forest communities are also endangered because of uncontrolled harvest by private forest owners. An increasing rate of forest cutting and sanitary cutting results in the loss of old and over-aged stands with large trees, dead trees, broken stems and trees with hollows, providing habitats for birds and rare xylophagous insect species [2].

Uncontrolled tourism and visitor activities along the sea endanger the unique costal and dune habitats, including embryonic shifting dunes and white dunes with Ammophila areanaria, coastal grey dunes, wooded dunes of the Atlantic, continental and boreal regions [2].

Main threats to the biological diversity and the breeding bird populations in the Lake Engure Nature Park are overgrowing of the lake by reeds and overgrowth of meadows both at the lake and the sea. Negative effects on the biodiverity of the region may cause violation of the nature protection regime at the Lake Engure Nature Park, including violation of fishing and hunting regulations, as well as the regulations concerning docking stations [2]. To estimate human impact on the biodiversity of the region and elaborate a strategy for the sustainable development of ecosystems, detailed studies of both the socioeconomic and ecological aspects of the region are necessary.

\section{REFERENCES}

1. Andrushaitis, G. (ed.) Red Data Book of Latvia. Rare and threatened plants and animals.Vol 3.Vascular plants. Riga: Institute of Biology, 2003

2. Anonymous, Management plan of the Lake Engures Nature Park. Riga: Latvian Fund for Nature, 2000. (In Latvian).

3. Auninšs, A., Zviedre, E., Brūmelis, G., Preliminary results of remote sensing based vegetation mapping of Lake Engures (Engure), Latvia. Proceedings of Latvian Academy of Sciences, 2000, Sect. B, 54 (5/6), p. 170-176.

4. Briede, A., Kḷaviñš, M., Rodinov, V. Chemical composition of Lake Engures (Engure), Latvia. Proceedings of Latvian Academy of Sciences, 2000. Sect. B, Vol.54, N5/6, p. 141-147.

5. Eberhards, G. Coastal dunes in Latvia. In: Environmental perspectives of Southeast Baltic coastal areas through time. Field Guide. Riga: University of Latvia, 1998, p. 18-25.

6. Eberhards, G., Saltupe, B. Geological history, relief, and deposits of the Lake Engure area along the Baltic Sea. Proceedings of Latvian Academy of Sciences, 2000. Sect. B, Vol. 54, N5/6, p.141-147. 
7. Gavrilova, G., Baronina, V. Vascular plant flora of the Lake Engures (Engure) drainage basin, Latvia, and the coastal zone of the Gulf of Riga. Proceedings of Latvian Academy of Sciences, 2000. Sect. B, Vol. 54, N 5/6, p. 177-189.

8. Grant, F., Young, J., Bridgewater, P., Watt, A.D. (Eds). Targets for biodiversity beyond 2010: research supporting policy. Report of an econference, 2009.

9. Haberl, H., Gaube, V., Díaz-Delgado, R., Krauze, K., Neuner, A, Peterseil, J., Plutzar, Ch., Singh, S. J., Vadineanu, A. Towards an integrated model of socioeconomic biodiversity drivers, pressures and impacts. A feasibility study based on three European long-term socioecological research platforms. Ecological Economics, 2009, Vol. 68, N 6, p.1797-1812

10. Hutson, M. A general hypothesis of species diversity. American Naturalist, 1979, N 113, p. 81-101.

11. Karpa, A., 2000. Flies (Diptera, Brachycera) of the Lake Engure Nature Park, Latvia. Proceedings of Latvian Academy of Sciences, 2000. Sect. B, Vol.54, N5/6, p. 203-212.

12. Kḷaviňš, M., Briede, A., Kḷaviṇa, I., Rodinov, V., 1995. Metals in sediments of lakes in Latvia. Environ. Int., Vol. 21, p. 451-458.

13. Laime, B., 2000. Seashore plant communities of the Lake Engures (Engure) Nature Park. Proceedings of Latvian Academy of Sciences, 2000. Sect. B, Vol.54, N5/6, p. 190-196.

14. Melecis, $\mathbf{V}$. Integrated research: the renaissance of ecology in Latvia Proc. Latvian Acad. Sci., 2000, Sect. B, Vol. 54, N 5/6, p. 221-225.

15. Naveh, Z. The Total Human Ecosystem: Integrating Ecology and Economics. BioScience, 2000, Vol. 50, N 4, p. 357-361.

16. Naveh, Z., Lieberman, A. S. Landscape ecology: Theory and Application. New York: Springer-Verlag, 1994.

17. Paulina, E., Salmane, I. Soil Collembola (Insecta) and Gamasina mites (Acari) of the reserve Lake Engure, Latvia. In: Elberg K., Martin M. Pekkarinen A.(eds.) Proceedings of $24^{\text {th }}$ Nordic Congress of Entomology, August 8-11, 1999,Tartu, Estonia, p. 145-150.

18. Pedroli, B., Van Doorn, A., De Blust, G., Paracchini, ML., Wascher, D \& Bunce, $\mathbf{F}$ (Eds.). Europe's living landscapes. Essays on exploring our identity in the countryside. LANDSCAPE EUROPE /Wageningen/ KNNV Publishing, 2007.

19. Seisuma, Z., Kulikova, I., 2000. Metals in sediment and water of the coastal zone of the Gulf of Rīga, The Baltic Sea. Proceedings of Latvian Academy of Sciences, 2000. Sect. B, Vol. 54, N 5/6, p. 148-154.

20. Springe, G., Druvietis, I., Parele, E., 2000. The plankton and benthos communities of the lagoon Lake Engures (Engure), Latvia. Proceeding of Latvian Academy of Sciences, 2000. Sect. B, Vol. 54, N 5/6, p. 164 169.

21. Strāke, S., 2000. Variations of mesozooplankton species composition, abundance, and biomass in the littoral zone of the Gulf of Riga, Latvia Proceedings of Latvian Academy of Sciences, 2000. Sect. B, Vol. 54, N 5/6, p. 155-159

22. Tabaka, L., Gavrilova, G., Fatare, I. Flora of vascular plants of the Latvian SSR. Riga: Publ. house Zinātne, 1988. (In Russian).

23. Vīksne, J. The bird lake Engure. Riga: Publishing House Jāṇa sēta. 1997.

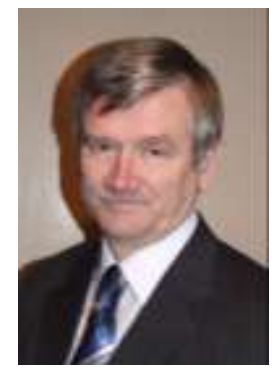

Viesturs Melecis (born in 1950) obtained his scientific degrees in biology at the University of Latvia and was working as a scientific researcher at the Institute of Biology since 1971. Since 1988 he is the Director of the Institute. Since $1994 \mathrm{~V}$. Melecis started teaching at the University of Latvia and at present he is a full professor at the Faculty of Geography and Earth Science. His main research is focused on ecology and environmental science. He is a coordinator of the Latvian National LTER network and leads several long-term research projects on climate warming effects and human influence on biodiversity in Latvia. He is the initiator of implementation of LT(S)ER platform in Latvia.

Address: Miera str. N3, LV-2169, Salaspils, Latvia

Phone: +371 67944988, Fax: +371 67944988

E-mail:vmelecis@email.lubi.edu.lv

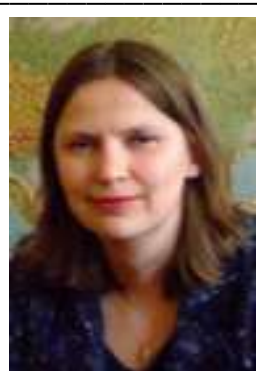

Zaiga Krisjane (born in 1963) obtained her scientific degree in geography at the University of Latvia. Since 1990 she started teaching at the University of Latvia and at present she is a full professor at the Faculty of Geography and Earth Science. Z. Krisjane is head of the Department of Human Geography of the University of Latvia. Her scientific interests lie in population geography, urbanization, migration and regional planning. She is the chair of the Latvian Geographical Society.

Address: Raina bulv 19, LV-1586, Riga, Latvia Phone: +371 67336373

E-mail: zaiga.krisjane@lu.1v

Maris Klavins (born in 1956) obtained his scientific degree in chemistry of biologically active compounds at the Moscow State University in 1986, but a

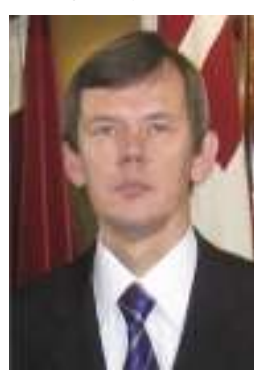
hition degree at the University off Latvia in 1994. M. Klavins worked in the Institute of Applied Biochemistry from 1982 till 1989, in the Institute of Biology from 1989 till 1993, but in the University of Latvia from 1993 where at present he is a full professor. M. Klavins is member of the Academy of Sciences of Latvia, coordinator of International humic substances research society (IHSS). Research interests are related to studies of natural organic matter, wetlands and bogs and environmental pollution problems. Address: Raina bulv 19, LV-1586, Riga, Latvia

Phone: +37167334096

E-mail: maris.klavins@lu.lv

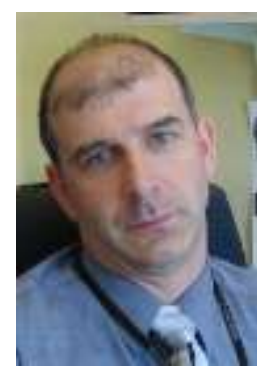

Juris Aigars (born in 1966) obtained his master's degree in chemistry at the University of Latvia in 1995 and in 2001 defended his PhD degree in biogeochemistry at the Stockholm University. From 1991 to 1995 was working at the Institute of Biology, but since 1995 is working at the Latvian Institute of Aquatic Ecology where at present is senior scientist. His main research is focused on biogeochemical cycles of elements mostly in marine environment. Address: Daugavgrivas 8, LV 1048, Riga, Latvia Phone/ Fax: +37167601995

E-mail: juris.aigars@1hei.lv

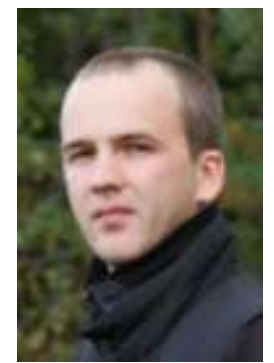

Didzis Elferts (born in 1980) obtained his scientific degree in biology at the University of Latvia in 2008 From 2002 till 2005 was working in the Latvian Environmental Agency, but in the University of Latvia from 2006 where at present he is a docent and senior researcher. His main research interests are related to impact of environmental factors on the radial growth of trees.

Address: Kronvalda bulv. 4, LV-1586, Riga, Latvia Phone: +37167033881

E-mail: didzis.elferts@lu.lv

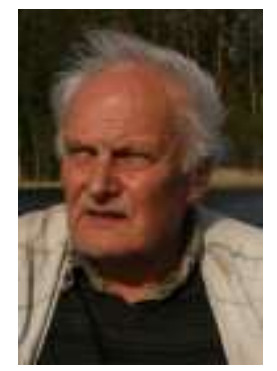

Janis Viksne (born in 1936) obtained his scientific degree in biology at the University of Latvia. He was working at the Institute of Biology since 1953. At present he is a leading researcher and professor of the Institute of Biology, University of Latvia. His field of studies is zoology in particular ornithology. For many years he conducted long-term projects in water bird population dynamics. He is a member of the Latvian Academy of Sciences. He represents the country in several international committees including the International Ornithological Committee and Wetlands International.

Address: Miera 3, LV-2169, Salaspils, Latvia

Phone: +3717945437, Fax: +3717944988

E-mail: ornlab@latnet.lv 
Viesturs Melecis, Zaiga Krišjāne, Māris Kḷaviṇš, Juris Aigars, Didzis Elferts, Jānis Vīksne. Socioekoloğiskie pētījumi Latvijā starptautiskā ilgtermiṇa ekoloǵisko pētījumu tīkla ietvaros

Ir sniegts pārskats par iepriekšējiem ekologiiskiem un sociālekonomiskiem pētījumiem, kas veikti sateces baseinā Engures ezerā. Pagājušajā gadsimtā tika publicēti biologiskās daudzveidības un ekosistēmas struktūras pētījumi reǵionā. Bet reǵionā līdz šim nav veikti īpaši sociālie pētījumi. Rakstā apskatīti agrāk veikto ekoloǵisko un sociāli ekonomisko pētījumu rezultāti Engures ezera sateces baseina teritorijā. Šì teritorija - Engures reǵions - ir izvēlēta kā ilgtermiņa sociāli ekologiisko pētījumu (LT(S)ER) platforma starptautiskā ILTER tīkla ietvaros. 2010. gadā uzsākts Latvijas Zinātnes padomes finansēts sadarbības projekts "Konceptuālā modeḷa izveidošana socioekonomisko faktoru spiediena novērtēšanai uz biodaudzveidību ilgtermiņa pētījumu model̦reǵionā Latvijā". Viens no projekta pirmajiem uzdevumiem ir informācijas apkopošana par Engures reǵiona ekoloǵiskajiem un sociāli ekonomiskajiem procesiem vēstures griezumā. Līdz šim veikti daudzi ekoloǵiskie pētījumi, taču trūkst integrētas informācijas par sociāli ekonomiskajiem procesiem, kas būtu jāliek pamatā konceptuālā modeḷa izveidei par cilvēka un dabas sistēmu mijiedarbību Engures reǵionā. Rakstā iztirzāti galvenie antropogēnie faktori, kas ietekmējuši Engures reǵiona biodaudzveidību pagātnē un mūsdienās.

Виестурс Мелецис, Зайга Кришьяне, Марис Клявиньш, Юрис Айгар, Дидзис Элферт, Янис Виксне. Социоэкологические исследования в Латвии в рамках проекта международных долгосрочных экологических исследований

Представлен отчет о предыдущих экологических и социально-экономических исследованиях, которые проводились в бассейне озера Энгурес. В прошлом веке публиковалось некоторое количество исследований о биологической структуре экосистемы и её разнообразности. Но до сих пор не были проведены особые социальные исследования. В статье рассматриваются результаты ранее проведенных экологических и социальноэкономических исследований в регионе водосбора озера Энгурес. Этот регион был выбран в качестве национальной платформы для долгосрочных социально-экологических исследований (LT(S)ER) в рамках международной сети долгосрочных экологических исследований (ILTER). B 2010 году был запущен проект, финансируемый Латвийским советом по науке “Создание концептуальной модели для оценки давления социально экономических факторов на биоразнообразие региона долгосрочных социально-экологических исследований (LT(S)ER)”. Oдна из первостепенных задач - обобщение существующей информации об экологических и социально-экономических процессах в регионе в историческом разрезе. В регионе до сих пор проводилось много экологических исследований, однако недостает обобщенных данных о социально-экономических процессах в регионе, которые можно было положить в основу создаваемой концептуальной модели взаимодействии человека и природных систем. В статье рассмотрены главные антропогенные факторы, которые оказали своё воздействие на биоразнообразие региона Энгурес в историческом аспекте и в настоящее время 